\title{
Engineering Economy: The Crossroads of Business, Engineering, and En- trepreneurship
}

\section{Dr. Paul C. Lynch, Penn State University Erie, The Behrend College}

Paul C. Lynch received his Ph.D., M.S., and B.S. degrees in Industrial Engineering from the Pennsylvania State University. Dr. Lynch is a member of AFS, SME, IIE, and ASEE. Dr. Lynch's primary research interests are in metal casting, manufacturing systems, and engineering education. Dr. Lynch has been recognized by Alpha Pi Mu, IIE, and the Pennsylvania State University for his scholarship, teaching, and advising. He received the Outstanding Industrial Engineering Faculty Award in 2011, 2013, and 2015, the Penn State Industrial \& Manufacturing Engineering Alumni Faculty Appreciation Award in 2013, and the Outstanding Advising Award in the College of Engineering in 2014 for his work in undergraduate education at Penn State. Dr. Lynch worked as a regional production engineer for Universal Forest Products prior to pursuing his graduate degrees. He is currently an Assistant Professor of Industrial Engineering in the School of Engineering at Penn State Erie, The Behrend College.

\section{Dr. Joseph Wilck, United States Air Force Academy}

Dr. Joe Wilck is an Assistant Professor of Operations Research at the United States Air Force Academy. $\mathrm{He}$ is a registered Professional Engineer. He is a volunteer leader with the Institute of Industrial Engineers (IIE) and the American Society for Engineering Education (ASEE). He is also an active member of INFORMS, MORS, INCOSE, and TRB. His research is in the areas of applied optimization and engineering education, and he has been funded by the National Science Foundation, the Department of Energy, DARPA, and the North Carolina Department of Transportation; among others. He primarily teaches courses in analytics, operations research, supply chain, and logistics.

\section{Dr. Omar Ashour, Pennsylvania State University Erie, The Behrend College}

Dr. Omar Ashour is Assistant Professor of Industrial Engineering at Pennsylvania State University, The Behrend College. Dr. Ashour received the B.S. degree in Industrial Engineering/Manufacturing Engineering and the M.S. degree in Industrial Engineering from Jordan University of Science and Technology (JUST) in 2005 and 2007, respectively. He received his M.Eng. degree in Industrial Engineering/Human Factors and Ergonomics and the Ph.D. degree in Industrial Engineering and Operations Research from Pennsylvania State University (PSU) in 2010 and 2012, respectively. Dr. Ashour's research areas include applied decision making and simulation. He contributed to research directed to improve engineering education. 


\title{
Engineering Economy: The Crossroads of Business, Engineering, and Entrepreneurship
}

\begin{abstract}
Creative minds often times have innovative ideas for designing products and services that may lead to successful businesses but these potential entrepreneurs often need an outside perspective from practitioners trained in business and engineering that can analyze potential ideas, perform engineering economic analyses, and help construct business plans to help entrepreneurs proceed in a fiscally responsible and systematic manner. Engineering economy is at the center of each and every business decision made in today's fast paced business world. Whether it be a rate of return analysis, payback analysis, net present worth analysis or a host of other engineering economic analyses, the ultimate decision to fund an engineering project, merger, acquisition, or to provide venture capital to an entrepreneur comes down to using the basic principles learned in engineering economy. This paper discusses the evolution of an engineering economy curriculum and the birth and success of a business and engineering student group that grew out of the engineering economy course that has grown from six to over 70 active members in just two years. All students in the student group completed the engineering economy course as sophomore or junior engineering students and have gone on to serve as financial advisers for the current engineering economy students, sponsor company case competitions, and most recently serve as consultants in the local community to help startup businesses. The paper discusses the evolution of the student group from the engineering economy course and the work of the entrepreneurship consulting group that is receiving much attention from program advisory board members, startup businesses, and university leadership.
\end{abstract}

\section{Disclaimer}

The views expressed in this paper are those of the authors and do not necessarily reflect the official policy or position of the U.S. Air Force, the U.S. Department of Defense, or the U.S. Government.

\section{Introduction and Motivation}

Company executives from Alcoa, ADT, and Armstrong among representatives from other companies that serve on the Industrial \& Professional Advisory Council (IPAC) and a Service Enterprise Engineering Advisory Board (SEE) in Industrial Engineering at Penn State University Park, expressed the need for the engineering economy class and its curriculum to serve as the crossroads between business, engineering, and entrepreneurship. The executives saw that one of the biggest deficiencies in young engineers entering their companies was the lack of a general knowledge of important business skills and the lack of application of the engineering economy curriculum prior to entering the work force. After collecting this feedback from the corporate executives it was evident that every engineering student should not only be exposed to the traditional engineering economy time value of money formulas but also key financial accounting topics with much emphasis on real life applications. The advisory board members expressed a 
pressing need for students to be exposed to business planning, financial statements and financial ratio analysis with special emphasis on understanding how engineering project decisions impact company financial statements ${ }^{1}$.

Shortly after the initial work was carried out to incorporate changes in the engineering economy course to address the key concerns of the advisory boards, the Penn State University President called upon faculty members to put special emphasis on developing business skills in all students. The university president called upon the faculty to "Invent Penn State: Let's turn discoveries into a great economy, together." 2 The president put forth a $\$ 30$ million investment in economic development and student career success in an effort to help reinvent and grow the local economy by bridging the gap between academia and business while helping great ideas get off of the ground in the local area with the help of untapped business and engineering talent from Penn State University ${ }^{2}$. The university president expressed the importance of developing deliberate strategies to promote economic development and a culture that rewards entrepreneurship. The main goal is to speed up the transfer of new ideas into useful products and processes that include but are not limited to energy, food security, environmental protection, health care, manufacturing educational technologies, medical devices and pharmaceuticals. Through the initial $\$ 30$ million investment, the president stood poised to build a stronger entrepreneurial ecosystem around the university's main campus and commonwealth campus system by hosting entrepreneurial boot camps and allowing individuals and student groups to both incubate their ideas while developing viable businesses. The work being carried out to bring together business and engineering within the Industrial Engineering Department at Penn State University Park was not carried out as a result of the president's initiatives. The industrial engineering business and engineering initiatives were being carried out prior to the announcement of the initiatives.

This paper was written with a focus of showing how a holistic approach (i.e. engineering economy curriculum changes including a company sponsored case competition, the evolution of a business and engineering student group from the engineering economy course, and a student led business consulting group) was taken in industrial engineering at Penn State University to give students the knowledge to develop essential business skills while also providing additional opportunities to apply and hone these skills through involvement in the student business and engineering group.

The evolution of the business and engineering student group and key connections made within their academic college and with local industry allowed the group to put together a business consulting group to strike right at the heart of the university president's main entrepreneurial initiative shortly after it was rolled out. The group was trained through their course work to a point where they were able to provide consulting work rooted in engineering economy for local business startups. The program advisory board members and the faculty adviser for the student group thought this was an opportunity like no other for students to gain on the job, real life business and engineering training while they were in school.

All three of the authors on this publication are currently teaching or have taught engineering economy at their respective schools within the past year. This current paper discusses the evolution of how the engineering economy curriculum evolved into a true business and 
engineering training course that prepared students to be part of a business and engineering consulting team as outlined above. The paper also explains how the Business and Engineering Group "B.E.G" student group evolved into a very successful chapter of the National Organization for Business and Engineering (NOBE) that has received much attention from the NOBE national board and other university chapters for their chapter's success and innovative ways of providing their chapter members with real life business and engineering and entrepreneurship training.

\section{Literature Review}

The literature shows that a vast number of researchers discuss the need to incorporate the significance of engineering economy to students within a business context. If there was one course in the engineering curriculum that one could say was at the cross roads of engineering, business, and entrepreneurship, one would have to believe that engineering economy is that course, Figure 1. The literature clearly shows evidence of engineering economy being at the crossroads of engineering, business, and entrepreneurship. "The importance and relevance of engineering economic analyses is always emphasized when students discuss their projects with practicing engineers. Without this interaction students sometimes consider economics to be irrelevant to design - a subject for business students," noted by Archibald, Reuber, and Allison ${ }^{3}$.

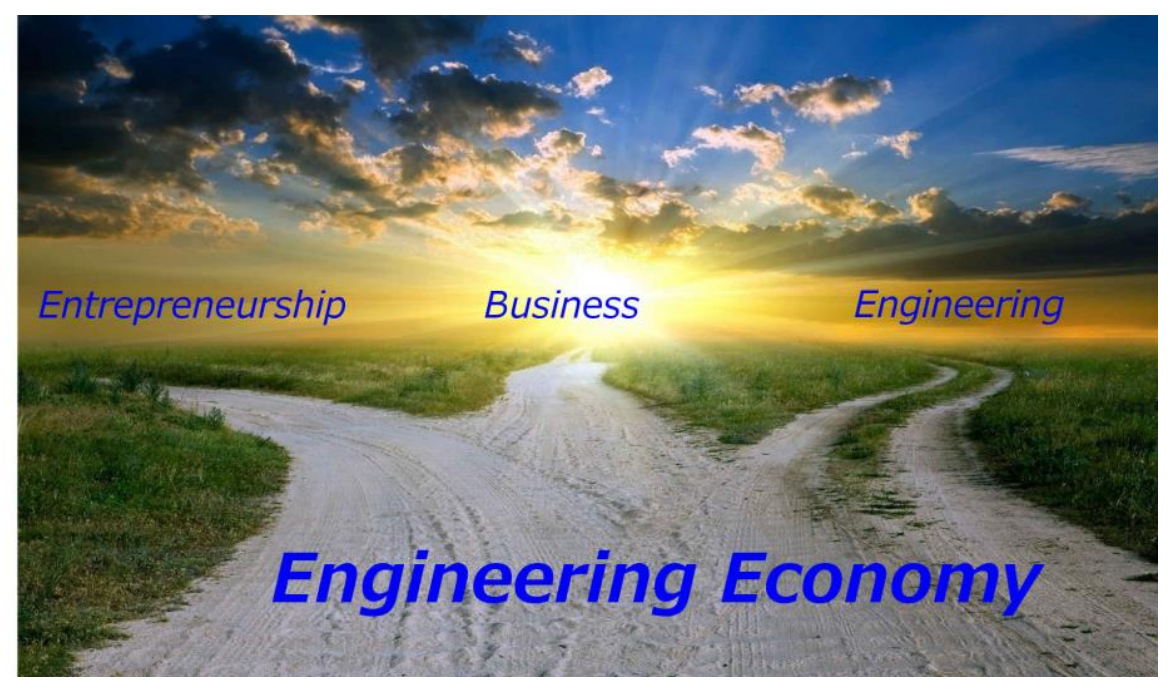

Figure 1: Engineering Economy: The course that is at the crossroads of business, engineering, and entrepreneurship.

Engineering education literature has continuously shown that projects with industry can be helpful for undergraduate and graduate students, even the processes of soliciting, administering, and managing industry projects that reinforce academic topics in engineering, technology, manufacturing, project management, lean, financial literacy, and six sigma ${ }^{1,4-11}$. Additional topics that are reinforced include professionalism (through interaction with industry), teamwork, and leadership ${ }^{12}$. These projects are also assessed as student work to meet the student learning outcomes $^{13}$. The results presented in one paper that reviewed student capstone projects indicated that first cost (initial cost) is the most significant metric, followed by annual worth, and payback (simple) within the students' analysis of their engineering design. Of these top three engineering 
economy metrics, the only metric that utilizes the time value of money concept is annual worth. However, the paper did note that over $40 \%$ of the teams used more than one analysis metric, which included methods such as net present value, rate of return, and benefit-cost ratio ${ }^{14}$.

Internships, cooperative (co-op) education programs have been supported by a number of articles in the engineering education literature. A recent article provides an overview of the University of Cincinnati's cooperative education program, which has been operating since 1906. Results show that the course has had a positive impact for students as they entered the workforce ${ }^{15}$. Texas A\&M researchers have discussed the benefits of an internship for both the student and the employer. The findings of the study indicate that expectations from both parties need to be communicated at the beginning of the internship with a firm structure for both the organization and culture of the work ${ }^{16}$.

Even though work has been done on talking about applying engineering economy to project work, there has not been work done that links engineering economy to an active business and engineering student group, a consulting team, and entrepreneurship initiatives where the skills learned in engineering economy are being practiced, honed, and applied.

\section{Evolution of the Business and Engineering Student Group}

The first year in existence for this student group was the 2013-2014 school year. The group was started by six industrial engineering students that were taking their required engineering economy course. The students wanted to learn more about the stock market, finance, and business startups. They reached out to the instructor of the engineering economy course and asked for the instructor's support to be their faculty adviser. This request was met and by the end of the 2013-2014 school year the group had 24 active members. During the 2014-2015 school year, the group grew to over 70 active members. The B.E.G. executive board members became immersed in helping to lead the charge to infuse additional real life business topics into the engineering economy curriculum. They served as financial advisers for a new semester long stock/ metals portfolio case study in the engineering economy course. Each of the financial advisers was assigned 4 to 5 case study groups within the engineering economy course they had previously completed. The financial advisers were responsible for monitoring the performance of the portfolios and sending each group a performance summary every 5 weeks. At the end of every 5 weeks, the advisers also put together a powerpoint presentation that displayed the Top 5 performing teams, Top 10/ Worst 10 performing stocks, and the performance of the precious metals. The course instructor started the engineering economy class with this update every 5 weeks. In addition to helping with the stock case study, the financial advisers also helped the student groups with their financial statement analysis. They attended class and took questions from their groups on how to calculate ratios and perform calculations from the given company financial statements. The B.E.G. executive board members were also actively involved with the first company sponsored case study competition in this engineering economy course. All of the executive board members of the student group had taken the engineering economy course and all had internship and/or co-op experience ${ }^{1}$. 
The explosive growth of the student group can be attributed to a number of factors. The "real life" work (i.e. stock case study, financial statement analysis on a well known company, investment case study, company sponsored case study) being carried out in the engineering economy course and the involvement of the student peers in the engineering economy were considered to be the main factors. Survey results taken after the first semester of the B.E.G. student involvement showed that $94.3 \%$ of the students (99 out of 105) said they liked the idea of having industrial engineering undergraduate students with internship experience involved with the case study experience in the engineering economy class. $70 \%$ of the students said that the B.E.G. students added value to the delivery of the course. Likewise, $70 \%$ of the students said the B.E.G. student involvement helped to spark their interest in the semester long stock and investment case study. $69 \%$ of the students said they were motivated to want to learn more about the engineering economy topics (namely financial statements, stocks, retirement) as a result of the B.E.G. student involvement in the course. In fact, $79 \%$ of the students would like to see industrial engineering undergraduate students with internship experience more involved with the delivery of the industrial engineering courses. Likewise, $79 \%$ of the students expressed interest in being part of B.E.G after taking the engineering economy course. In addition to the B.E.G. interest sparked within the engineering economy class and curriculum, interest was also generated at general body B.E.G. meetings. Within the business and engineering group meetings, the current members stressed the importance of having business skills to complement their engineering skills. The business and engineering group brought in one key note corporate speaker each semester that stressed the importance of the connection between business and engineering. At the end of the 2014-2015 school year, B.E.G. officially became a student chapter of the National Organization for Business and Engineering (NOBE).

\section{What is NOBE?}

The National Organization for Business and Engineering (NOBE) was founded in 2006 by a similar student chapter at the University of Illinois. It is a nationally recognized organization that sets out to unite those with business and engineering backgrounds and the corporate and academic levels. The organization strives to produce leaders that can be translated into success in the business world. NOBE offers its student members' professional development, corporate interaction, graduate education, and current business and market training opportunities. Today, NOBE student chapters exist at the University of Illinois, University of Wisconsin, Drexel University, Purdue University, Northwestern University, Iowa State University, University of Minnesota, University of Southern California, San Jose State University, McGill University, Penn State University Park, Penn State Behrend, Georgia Tech, New York University, University of Florida, and the University of Texas- Austin ${ }^{17}$. This national organization has seen much success since its inception in 2006 and has produced highly integrated individuals driven by their success in academia and business.

NOBE hosts a national conference every year that brings together the national board, student chapters, faculty advisers, and corporate sponsors and speakers. NOBE also hosts an annual Stock Market competition for its members ${ }^{17}$. 


\section{Penn State University Park NOBE Initiatives}

The NOBE chapter at Penn State University Park grew out of the engineering economy course within industrial engineering. The NOBE students embraced the curriculum overhaul in the engineering economy course and volunteered their time to work with the incoming engineering economy students in an effort to help them understand the importance of developing essential business skills to complement their technical, engineering education. The complete, updated engineering economy curriculum can be found in Table A.1 in the Appendix.

\section{Engineering Economy Curriculum Overhaul, Stock Competition}

The complete curriculum overhaul included multiple additions to the current engineering economy curriculum. First, lectures were added to cover the following topics: business planning, financial statements (with emphasis on the balance sheet and income statement), financial accounting and ratio analysis, and activity based costing. Next, a stock investment portfolio case study was added to the class. The main objective of the stock case study was to help students completely understand the "big picture" of making their engineering economic decisions. A second case study on company financial statement analysis was added. The students were now able to carry out engineering economic analyses and be able to understand how these engineering decisions effect company financial statements and eventually stock price. Lectures on mortgages and car loans were also added to bring the engineering economy curriculum into the students' personal lives. Furthermore, a lecture unit was added to address IRA, 401K, and bond investments. The third case study added was a case study on retirement planning using Roth and Traditional IRAs, 401K, and bond investments.

The NOBE executive board members worked with their faculty adviser who is also the instructor of the engineering economy course at Penn State University Park to carry out the semester long case study experience within the engineering economy course each semester ${ }^{1}$. As mentioned previously, the executive board members embraced the role of financial advisers to help the teams manage their investment portfolios throughout the semester. The semester long stock competition helped the instructor make the very important connection between company stock prices, financial statements, and engineering economic analyses and decisions. For the vast majority of the engineering economy students, this was the first time they had ever learned about stocks and investment portfolios.

After implementing the changes to the engineering economy course and introducing the involvement of the NOBE students into the course for the first time, initial student satisfaction data was collected. Unfortunately, the instructor was unable to collect data prior to the curriculum changes being made in the course. Prior to taking the engineering economy course, only $22.4 \%$ of the students (19 out of 85 ) said they had any knowledge of financial statements, financial accounting, and finance. After taking the engineering economy course, $98.8 \%$ of the students (84 out of 85) said they felt as though it was important for them as an engineering student to understand financial statements, financial accounting, and finance. $100 \%$ of the students (85 out of 85) felt as though the engineering economy course did a good job of teaching them the importance of understanding how engineering decisions impact financial statements 
and the bottom line of the company. Likewise, $100 \%$ of the students ( 85 out of 85 ) felt as though the engineering economy course did a good job of teaching them how to manage their own personal finances. The mean for the overall quality of the course was rated as 6.81 out of a possible 7.00. The mean for the overall quality of the instructor was rated as 6.95 out of a possible 7.00. The student rating results showed that the industrial engineering students were overwhelmingly satisfied with their learning experience in the engineering economy course ${ }^{1}$.

\section{Case Competitions}

One of the significant curriculum changes to the engineering economy course was the inclusion of a case competition. The motivation to make the changes to the curriculum was prompted by the advisory and alumni boards of the program. The importance of the case competition was reflected by the survey outcomes of the students (including both attitude changes to working in different industries and/or interest in new topics and achievement of course learning goals) and a survey of the industry participants ${ }^{1}$.

In addition to the course lecture and case study changes noted above, the NOBE student group and the engineering economy instructor worked with a large U.S. retailer to bring a real life company sponsored project into the engineering economy classroom to be the subject of a case competition. As part of the final report, the engineering economy students had to provide a cost analysis and economic justification, where the students had to sell their ideas to the U.S. retailer's engineering and management team ${ }^{1}$. 29 groups (4 students in each group) competed in the competition. After the initial cuts were made, 5 student groups competed in the final round, presenting their work to a lineup of 8 corporate judges. It was a real life, corporate board room setting where students were grilled by the judges after each of their presentations. The top three teams received scholarships. The first place team was awarded $\$ 1,500$. Second place received $\$ 1,000$. The third place team was awarded $\$ 500$. The results of the competition were overwhelmingly positive. Over $91 \%$ (101 out of 110) of the students said they would like to see similar case study experiences in more of their industrial engineering courses. After completing this case study experience, $99.1 \%$ of the students (109 out of 110) felt as though they had a better understanding of how they would conduct an industrial engineering study and sell their work to upper level management using an engineering economic/ financial justification. The average student rating for the overall case study learning experience was 4.1 out of 5 . Over $88 \%$ of the students rated the overall experience as being satisfying or extremely satisfying. The average company sponsor rating for the overall case study learning experience was 4.8 out of 5 . A summary of the questions and responses from the student case study questionnaire are shown in Table 1 below. A summary of the questions and responses from the industry sponsor case study questionnaire are shown in Table 2 below. 
Table 1: Summary of Student Engineering Economy Case Study Feedback Questionnaire Data.

\begin{tabular}{|c|c|c|}
\hline Question & Frequency & Answers \\
\hline \multirow{2}{*}{$\begin{array}{l}\text { Do you feel as though the case study } \\
\text { experience added value to the Engineering } \\
\text { Economy Course? }\end{array}$} & 105 & Yes \\
\hline & 5 & No \\
\hline \multirow{2}{*}{$\begin{array}{l}\text { Do you feel as though the Case Study Topic } \\
\text { was a good fit for your Engineering } \\
\text { Economy Course? }\end{array}$} & 98 & Yes \\
\hline & 12 & No \\
\hline \multirow{2}{*}{$\begin{array}{l}\text { When compared to completing an } \\
\text { assignment solely for a grade, do you feel as } \\
\text { though the competition component of the } \\
\text { study motivated you to try harder on this } \\
\text { assignment? }\end{array}$} & 87 & Yes \\
\hline & 23 & No \\
\hline \multirow{2}{*}{$\begin{array}{l}\text { Would you like to see similar case study } \\
\text { experiences in more of your industrial } \\
\text { engineering courses? }\end{array}$} & 101 & Yes \\
\hline & 9 & No \\
\hline \multirow{2}{*}{$\begin{array}{l}\text { After completing this case study experience, } \\
\text { do you feel as though you now have a better } \\
\text { understanding of how you would conduct an } \\
\text { industrial engineering study and sell your } \\
\text { work to upper level management using an } \\
\text { engineering economic/ financial } \\
\text { justification? }\end{array}$} & 109 & Yes \\
\hline & 1 & No \\
\hline \multirow{4}{*}{$\begin{array}{l}\text { Please rate your overall case study learning } \\
\text { experience }\end{array}$} & 1 & Unsatisfying (2) \\
\hline & 12 & Neutral (3) \\
\hline & 73 & Satisfying (4) \\
\hline & 23 & Extremely Satisfying (5) \\
\hline \multirow{3}{*}{$\begin{array}{l}\text { What did you like most about the case study } \\
\text { experience? }\end{array}$} & 60 & Real world problem solving \\
\hline & 7 & Enjoyed the competition aspect \\
\hline & 4 & Freedom to be creative \\
\hline \multirow{3}{*}{$\begin{array}{l}\text { What do you feel as though could be done to } \\
\text { improve the case study experience? }\end{array}$} & 21 & $\begin{array}{l}\text { More Information given in the project } \\
\text { problem statement }\end{array}$ \\
\hline & 7 & $\begin{array}{l}\text { Less assumptions and more precise data } \\
\text { given }\end{array}$ \\
\hline & 16 & $\begin{array}{l}\text { More Q\&A, Communication, or more } \\
\text { communication time with sponsor }\end{array}$ \\
\hline
\end{tabular}


Table 2: Summary of Sponsor Engineering Economy Case Study Feedback Questionnaire Data.

\begin{tabular}{|c|c|c|}
\hline Question & Frequency & Answers \\
\hline \multirow{2}{*}{$\begin{array}{l}\text { Where do you spend most of your } \\
\text { time in your current position } \\
\text { (circle only one)? }\end{array}$} & 3 & Field Engineering Manager \\
\hline & 5 & Distribution Center \\
\hline \multirow{3}{*}{$\begin{array}{l}\text { What are the main reasons (goals) } \\
\text { for partnering with Penn State } \\
\text { Industrial Engineering faculty to } \\
\text { carry out this case study } \\
\text { experience? }\end{array}$} & 6 & $\begin{array}{l}\text { Branding of Company and talent acquisition/ future } \\
\text { IE candidates. }\end{array}$ \\
\hline & 2 & Create a partnership with Penn State IE. \\
\hline & 2 & Present Real World Issues to Students. \\
\hline \multirow{5}{*}{$\begin{array}{l}\text { What did you like most about the } \\
\text { case study experience? }\end{array}$} & 5 & Creativity \\
\hline & 1 & Great results \\
\hline & 1 & Visibility to students \\
\hline & 1 & Creating a challenging project for students \\
\hline & 3 & Great presentations \\
\hline \multirow{6}{*}{$\begin{array}{l}\text { What do you feel as though could } \\
\text { be done to improve the case study } \\
\text { experience? }\end{array}$} & 2 & $\begin{array}{l}\text { Add a Virtual Q\&A Session/ add another Q\&A } \\
\text { session with Company employees }\end{array}$ \\
\hline & 1 & $\begin{array}{l}\text { Have presentations at night so there is more time to } \\
\text { present }\end{array}$ \\
\hline & 2 & Offer more information at presentation session \\
\hline & 1 & Judging and Company introductions \\
\hline & 1 & Give more feedback to students \\
\hline & 1 & Invite students to tour a distribution center \\
\hline \multirow{2}{*}{$\begin{array}{l}\text { Rate your overall case study } \\
\text { experience }\end{array}$} & 2 & Satisfied (4) \\
\hline & 6 & Extremely Satisfied (5) \\
\hline \multirow{2}{*}{$\begin{array}{l}\text { Do you feel as though you would } \\
\text { be interested in sponsoring a } \\
\text { similar case study experience in } \\
\text { the future with the Industrial } \\
\text { Engineering Faculty at Penn } \\
\text { State? }\end{array}$} & 8 & Yes \\
\hline & 0 & No \\
\hline \multirow{2}{*}{$\begin{array}{l}\text { If you answered YES to the } \\
\text { previous question above, do you } \\
\text { feel as though you would be } \\
\text { interested in making this an } \\
\text { annual event in this course } \\
\text { (Engineering Economy) with the } \\
\text { Industrial Engineering Faculty at } \\
\text { Penn State? }\end{array}$} & 8 & Yes \\
\hline & 0 & No \\
\hline
\end{tabular}

\section{Penn State University Park NOBE Consulting Team}

Last school year, the president of the NOBE student group at Penn State University Park was the first student to begin working as a consultant for a local start up incubator near the campus. After last school year, the NOBE group worked with their faculty adviser and faculty members in both the College of Business and College of Engineering to put a formal consulting model in place. A faculty member in the College of Engineering quoted, "Time and again, start-ups and 
small firms in town were looking for good engineering talent to help take their company to the next level, but their resources were very limited. NOBE's interest in providing consulting services seemed like a great place to start." 18 The consulting team prepared a proposal for a local entrepreneur and CEO of a Business Development company to work with him as consultants for a logistics company that provides forward shipping services across the U.S. The proposal to work with the local entrepreneur and the logistics company was accepted. This paved the way for ten industrial engineering NOBE students to gain real life business and engineering consulting experience while working with a well-known, local entrepreneur. A faculty member in the college of Engineering quoted, "The local entrepreneur and CEO of the Business Development company was an ideal person to partner with on NOBE's first consulting project. He knows how to work with students, and he was willing to really engage them in his company's operations and challenge them to apply their engineering skills to a real business environment." 18

All of the student consultants in the group successfully completed the engineering economy course taught by the NOBE faculty adviser. The consulting team was overseen by the NOBE student chapter president. The president broke the students down into three subgroups:

Logistics, Technology, Sales/Customer Service. The logistics team examined existing partnerships of this logistics company with other similar companies to evaluate the profitability of the current partnerships in an effort to increase profits for future partnership agreements. The technology team investigated different business software the logistics company could use to streamline sales tracking and logistics. The sales/ customer service team conducted statistical analysis projects to find correlations amount locations, customers, and current customer pricing in an effort to increase sales and profit margins. The team worked through one semester and at the end of the semester, each team prepared final project recommendations complete with engineering economic evaluations. The teams were required to give formal business presentations, complete with professional business dress attire to the local CEO and well known entrepreneur, Figure 2.

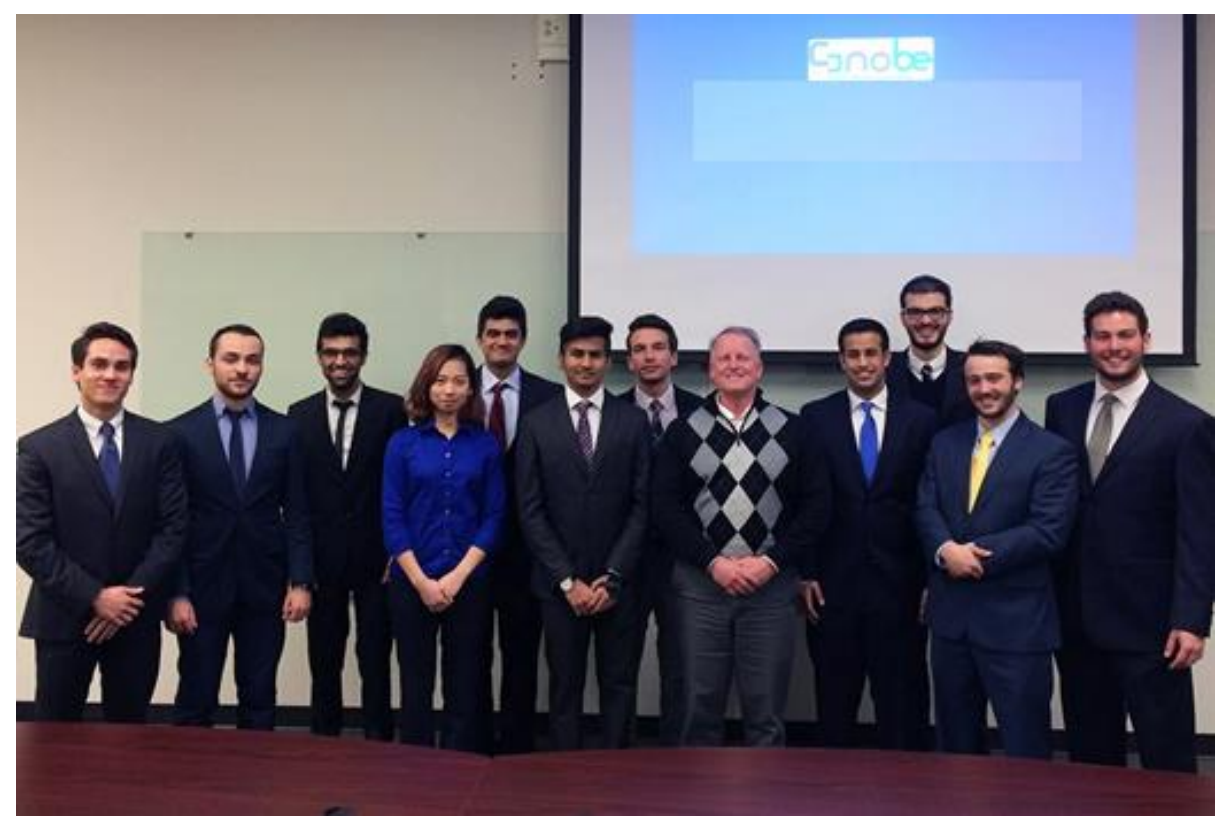

Figure 2: The NOBE student consulting team prepared final business presentations for a local CEO and well known entrepreneur on Logistics, Technology, Sales/ Customer service. 


\section{NOBE Consulting Team Feedback}

After the story of the NOBE consulting team was published, the group was widely recognized by the Penn State University community for their unique approach to combining business and engineering. A retired, well known CEO commented on the NOBE group with regard to their work in the service industry, "This will create jobs for our students focused on improving the productivity and quality of these business, allowing them to create successful careers for themselves." 18 The retired CEO also lauded the NOBE effort working in the service sector of the economy as he noted that the U.S. service industry currently employs over $80 \%$ of workers, with the number steadily increasing. The local entrepreneur and CEO of the Business Development Company summed up the relationship with the consulting team by saying, "Working with the NOBE consulting group brings a valuable perspective that is often missing from business, especially smaller business. I have found that the NOBE engineers bring a set of skills that my company does not possess, and their ability to provide specific, actionable suggestions is invaluable." 18

Two of the authors of this paper are currently working with a think tank group at Penn State Behrend to strengthen the NOBE chapter at the second location and also to mimic the consulting idea in an effort to get the students to potentially become part of the "Ignite Erie" initiative underway at this campus location in the heart of a once thriving manufacturing base in need of an economic rebirth.

\section{Penn State University Park NOBE Chapter Initiatives Receive National Attention}

In the short time since its inception, this NOBE student chapter quickly captured the attention of prominent alumni, entrepreneurs, and faculty members. This unique approach of growing the NOBE student group out of the engineering economy course and reinforcing the importance of the engineering course to incoming students along with bringing corporate sponsors into the group became the focal point of the 2015 NOBE National Conference. The evolution of the engineering economy curriculum and the innovative work being completed by the student group received special recognition by the National Organization for Business and Engineering (NOBE). The student chapter being discussed was selected as the host for the 2016 National Conference for NOBE. The 2016 NOBE conference will be held at Penn State University Park in mid-February 2016.

\section{Summary of Student Outcome Feedback Results}

The goal of the curriculum changes was to give students the necessary business skills that were noted as "lacking" by companies hiring industrial engineering students from Penn State University Park. After the first semester of implementation of the new curriculum, the student feedback was remarkable. Prior to taking the engineering economy course, only $22.4 \%$ of the students (19 out of 85) said they had any knowledge of financial statements, financial accounting, and finance. After taking the engineering economy course, $98.8 \%$ of the students (84 out of 85) said they felt as though it was important for them as an engineering student to 
understand financial statements, financial accounting, and finance. $100 \%$ of the students (85 out of 85) felt as though the engineering economy course did a good job of teaching them the importance of understanding how engineering decisions impact financial statements and the bottom line of the company.

A company case study competition experience was integrated into the course in addition to the stock, financial statement, and retirement case studies. The feedback received from the students on this experience was also remarkable. $95.5 \%$ of the students (105 out of 110$)$ said that the case study competition experience added value to the engineering economy course. $91.8 \%$ of the students (101 out of 110) responded saying they would like to see similar case study experiences in more of their industrial engineering courses. After completing this case study experience, $99.1 \%$ of the students (109 out of 110) felt as though they had a better understanding of how they would conduct an industrial engineering study and sell their work to upper level management using an engineering economic/ financial justification.

This qualitative and quantitative feedback received over multiple semesters regarding the engineering economy curriculum changes and the case competition was overwhelmingly positive and led to the following conclusions and ideas for future work.

\section{Conclusions and Future Work}

This paper details a holistic plan in the industrial engineering program at Penn State University Park to give students essential business skills while also providing additional opportunities for students to apply and hone these skills through involvement in the student NOBE group. To implement this approach, multiple changes were made to the engineering economy curriculum including the addition of a company sponsored case competition. A business and engineering student group evolved from the engineering economy course and a student led business consulting group evolved from the student group.

The overwhelming popularity of the NOBE student group and the feedback received on the curriculum changes show that this initiative was an absolute success story. The engineering economy course provided the students with the foundational engineering economic and corporate finance knowledge necessary to bridge the gap between business and engineering. The engineering economy curriculum changes that included real life stock and case competitions motivated the students to want to learn more and expressed the importance for engineers to have knowledge of these important business topics. The involvement of the NOBE student group in the engineering economy course and their enthusiasm for the material helped to motivate the students taking the engineering economy course. In fact, the motivation that was spearheaded by the NOBE group led to a rapidly growing student group that spawned a group of successful student consultants working with a prominent entrepreneur and CEO of a Business Development Company. The hope is that the engineering economy course model can be used in other academic institutions to spearhead similar business and engineering initiatives. This study shows proof that engineering economy is truly at the crossroads of business, engineering, and entrepreneurship. 
This study does lead to questions of further inquiry:

- Can this business and engineering initiative be adopted in engineering economy courses within industrial engineering and/or engineering at other universities?

- Can the business and engineering consulting model be repeated at other campus locations of this large university? At other universities?

- Can the national organization (NOBE) take the lessons learned from this student chapter and apply the successes to other chapters?

- Can additional programmatic changes be made to aid in local startup incubators and satisfy learning goals in specific engineering courses?

\section{Disclaimer}

The views expressed in this paper are those of the authors and do not necessarily reflect the official policy or position of the U.S. Air Force, the U.S. Department of Defense, or the U.S. Government.

\section{References}

1. Lynch, P.C., Bober, C., Wilck, J.H., "An Integrated Approach to Developing Business Expertise in Industrial Engineering Students," Proceedings of the 2015 ASEE Annual Conference \& Exposition, 2015.

2. Barron, E., "Invent Penn State: Let's turn great discoveries into a great economy, together" Penn State News, January $8^{\text {th }}, 2015$.

3. Archibald, M., Reuber, M., Allison, B., "Reconciling Well-defined Capstone Objectives and Criteria with Requirements for Industry Involvement," Proceedings of the 2002 American Society for Engineering Education Annual Conference \& Exposition, 2002.

4. Gibson, J.D., Brackin, M.P., "Techniques for the Implementation and Administration of Industrial Projects for Engineering Design Courses," Proceedings of the 1999 American Society for Engineering Education Annual Conference \& Exposition, 1999.

5. Noble, J. "An Approach for Engineering Curriculum Integration in Capstone Design Courses," International Journal of Engineering Education, 14(3), 197-203, 1998.

6. Vila-Parrish, V., Raubenheimer, D., "Integrating Project Management \& Lean-Six Sigma Methodologies in an Industrial Engineering Capstone Course," Proceedings of the 2012 American Society for Engineering Education Annual Conference \& Exposition, 2012.

7. Lamancusa, J., Jorgensen, J., Zayas-Castro, J., Ratner, J., "THE LEARNING FACTORY - A new approach to integrating design and manufacturing into engineering curricula," Proceedings of the 1995 American Society for Engineering Education Annual Conference \& Exposition, 1995.

8. Lynch, P.C., Wilck, J.H., Bober, C., Mines, J.L., "A New Look at Involving Undergraduate Students, Real Life Applications, and Active Learning Activities in the Industrial Engineering Undergraduate Course Delivery Process," Proceedings of the 2014 ASEE Annual Conference \& Exposition, 2014.

9. Sawhney, R.S., Maleki, S., Wilck, J.H., Hashemian, P., "Center for Productivity Innovation's Student Project with Industry Program at the University of Tennessee, Department of Industrial and Systems Engineering," INFORMS Transactions on Education, 13(2), 83-92, 2013.

10. Lynch, P.C., Bober, C., Wilck, J.H., "Educating and Training the Next Generation of Industrial Engineers to Work in Manufacturing," Proceedings of 2015 ASEE Annual Conference \& Exposition, 2015.

11. Wilck, J.H., Lynch, P.C., Kauffmann, P.J., "Engineering Economics as a General Education Course to Expand Quantitative and Financial Literacy," Proceedings of the 2014 ASEE Annual Conference \& Exposition, 2014. 
12. Dutson, A., Todd, R., Magleby, S., Sorensen, C., "A Review of Literature on Teaching Engineering Design Through Project-Oriented Capstone Courses," Journal of Engineering Education, 86(1), 17-28, 1997.

13. Kauffman, P., Dixon, E., "Vetting Industry Based Capstone Projects Considering Outcome Assessment Goals," International Journal of Engineering Education, 27(6), 1231-1237, 2011.

14. Dixon, E., Wilck, J.H., "Integrating Economic Analysis into Capstone Design," Proceedings of the 2014 ASEE Annual Conference \& Exposition, 2014.

15. Watson, J., Schomaker, M.G., "Introduction to Cooperative Education-The Course," Proceedings of the 2014 American Society for Engineering Education Annual Conference \& Exposition, 2014.

16. Rangan, S., Natarajarathinam, M., "How to structure an internship that is great for the intern and the manager?," Proceedings of the 2014 American Society for Engineering Education Annual Conference \& Exposition, 2014..

17. NOBE National Website, "About NOBE," https://www.nobenational.org/national/home.php, accessed February 1, 2016.

18. Wertz, Pamela, K., "Student Group Bridges the Gap Between Engineering and Business," Penn State News, December 4, 2015. 


\section{Appendix}

Table A.1: Detailed Engineering Economy Course Outline

\begin{tabular}{|c|c|}
\hline Unit & Topics \\
\hline Intro. & Introduction to Time Value of Money \\
\hline 1 & $\begin{array}{l}\text { Applications of Engineering Economics, Interest and Time Value of Money, Simple and Compound } \\
\text { Interest Rates }\end{array}$ \\
\hline 2 & $\begin{array}{l}\text { Economic Equivalence, Single Cash Flows (Present Value, Future Worth), Solving for (i) and (n), } \\
\text { Unequal Lengths of Interest Period and Cash Flow Period }\end{array}$ \\
\hline 3 & Equal Payment or Uniform Series, Sinking Fund Factor (A/F, i, n), Capital Recovery Factor (A/P, i, n) \\
\hline 4 & $\begin{array}{l}\text { Principal Amount and Interest Amount Included in Loan Payments, Present Value of Perpetuities, Linear } \\
\text { Gradient Series, Present Worth Factor: Linear Gradient Series (P/G, i, n) }\end{array}$ \\
\hline 5 & $\begin{array}{l}\text { Gradient-to-Uniform Series Factor (A/G, i, n), Geometric Gradient Series, Geometric Present-Worth } \\
\text { Factor }\left(\mathrm{P} / \mathrm{A}_{1}, \mathrm{~g}, \mathrm{i}, \mathrm{n}\right) \text {, Composite Cash Flows, Continuous Compounding }\end{array}$ \\
\hline 6 & $\begin{array}{l}\text { Business Planning, Financial Statements, Financial Accounting and Ratio Analysis, Activity Based } \\
\text { Costing }\end{array}$ \\
\hline 7 & $\begin{array}{l}\text { Continuous Compounding, Effect of inflation, Average Inflation Rate, Time Value of Money with } \\
\text { Inflation, Actual Dollar Analysis or "Then Current Analysis, Constant Dollar Analysis }\end{array}$ \\
\hline 8 & $\begin{array}{l}\text { Comparison of Engineering Projects, Payback Analysis (Conventional and Discounted), PW Analysis } \\
\text { (Net Present Worth and Net Present Value), Annual Cash Flow Analysis, Rate-of-Return Analysis, } \\
\text { Selecting a MARR, Investment Pool Concept, Borrowed Funds Concept, Net Future Worth and Project } \\
\text { Balance }\end{array}$ \\
\hline 9 & $\begin{array}{l}\text { apitalized-Equivalent Method, Perpetual Service Life, Service vs. Revenue Projects, Evaluating Projects } \\
\text { ith Equal Analysis Periods and Lives, Evaluation Projects with Unequal Analysis Periods and Lives }\end{array}$ \\
\hline 10 & $\begin{array}{l}\text { Annual Equivalent Worth Criterion, Comparing a Set of Projects, Finding Annual Equivalent Worth by } \\
\text { Conversion From NPW, Capital (Ownership) Costs versus Operating Costs, Calculating Capital Recovery } \\
\text { Cost, Applying Annual-Worth Analysis, Unit-Profit or Unit-Cost Calculation }\end{array}$ \\
\hline 11 & $\begin{array}{l}\text { ake or Buy Decisions, Comparison of Mutually Exclusive Projects (Unequal and Equal Project Lives), } \\
\text { nnual Equivalent Cost Comparisons }\end{array}$ \\
\hline 12 & $\begin{array}{l}\text { Rate of Return, Return on Investment, Return on Invested Capital, Internal Rate of Return, Simple vs. } \\
\text { Non Simple Investments (Borrowing and Lending), Computational Methods (Direct-Solution, Trial-and- } \\
\text { Error), Bonds, Yield to Maturity }\end{array}$ \\
\hline 13 & $\begin{array}{l}\text { Decision Rule for Simple Investments, Decision Rule for Non Simple Investments, Incremental Analysis } \\
\text { for Comparing Mutually Exclusive Alternatives, Flaws in Project Ranking by IRR, Incremental- } \\
\text { Investment Analysis, IRR on Incremental Investment Alternatives, Incremental Analysis for Cost-Only } \\
\text { Projects }\end{array}$ \\
\hline 14 & $\begin{array}{l}\text { Mortgages, Fixed Rates, Adjustable Rates, Refinance Decision, Payback Analysis, Pay-Off Balance } \\
\text { Calculations, Interest and Principal Calculations, Credit Scores }\end{array}$ \\
\hline 15 & $\begin{array}{l}\text { Accounting for Depreciation and Income Taxes, Depreciation and Cost Basis, Useful Life and Salvage } \\
\text { Value, Depreciation Methods: Book and Tax Depreciation, Straight Line Method, Declining Balance } \\
\text { Method, Depreciation Rates, Switching Policy, Units-of -Production Method, Tax Depreciation Methods, } \\
\text { MACRS Recovery Periods, Switching from DB to the SL Method, MACRS Depreciation of Real } \\
\text { Property }\end{array}$ \\
\hline & $\begin{array}{l}\text { Additional Case Study Topics: Retirement Planning, Traditional IRA, Roth IRA, 401K, Savings } \\
\text { Accounts, Tax Implications, Stock and Bond Investments }\end{array}$ \\
\hline
\end{tabular}

